\title{
Beneficial Effects of Bioactive Peptides Derived from Soybean on Human Health and Their Production by Genetic Engineering
}

\author{
Chin Feng Liu and Tzu Ming Pan \\ Department of Biochemical Science and Technology, College of Life Science, \\ National Taiwan University \\ Taiwan
}

\section{Introduction}

Soybean [Glycine max (L.) Merrill] is one of the oldest cultivated crops of the Far East. For centuries, the Oriental people, including the Chinese, Japanese, Koreans, and Southeast Asians, have used soybean as a staple source of dietary protein and oil. It is one of the five commercial food crops, besides rice, wheat, barley, and millet. Soybean is very important for vegetarians and vegans because of its high protein content and abundance of vitamins, minerals, and fiber. Because of its versatility, it can be prepared into a variety of foods, including fermented and nonfermented foods.

Asians consume about 20-80 g of traditional soy foods daily, the most common being tofu, miso, and tempeh (Fournier et al., 1998; Messina \& Flickinger, 2002), whereas Americans consume only about 1-3 g daily (Cohen et al., 2000; Fournier et al., 1998), mostly in processed forms such as soy drinks, breakfast cereals, and energy bars. Soybean-based foods have generated much interest because of the evidence that consumption of large amounts of soybean can lower the risk of chronic diseases such as cardiovascular disease and cancer; this effect is particularly noticeable among Asian populations because of their high soy food intake (Kulling et al., 2001; Persky et al., 2002; Tikkanen \& Adlercreutz, 2000). In addition, consumption of soy foods may reduce the risk of osteoporosis and help alleviate menopausal symptoms (Genovese \& Lajolo, 2002; Messina, 2000; Persky et al., 2002), which are major health concerns for women.

Soybean-based foods contain an array of biologically active compounds that can confer important health benefits such as antioxidant effects (Setchell, 1998; Tsai \& Huang, 1999). These phytochemicals include saponins, phytates, protease inhibitors, phenolic acids, and lecithin, all known for their anticancer potential (Cohen et al., 2000; Messina \& Flickinger, 2002); phytosterols, which have hypocholesterolemic effects; isoflavones, which are known for several health benefits (Fukui et al., 2002); and omega-3 fatty acids, which have wellrecognized cardioprotective effects. Among these compounds, isoflavones have attracted the most attention (Messina \& Flickinger, 2002; Messina \& Loprinzi, 2001).

The proteins $\beta$-conglycinin (7S globulin) and glycinin (11S globulin) constitute up to $90 \%$ of the total soy protein (Gianazza et al., 2003). Evaluation of these dietary proteins is very interesting because their hydrolysis by proteases produces peptides with biological activities. A growing 
body of scientific evidence has revealed that many food proteins and peptides exhibit specific biological activities in addition to their established nutritional value. Bioactive peptides present in foods may help to reduce the worldwide epidemic of chronic diseases. Functional proteins and peptides are now an important category within the nutraceutical food sector.

Many bioactive peptides have been isolated from soybean. Numerous studies of the enzymatic or chemical hydrolysis of soybean proteins have demonstrated their functional properties and physiological effects such as antimicrobial, antifungal, anticancer, antiobesity, antihypertensive, anti-inflammatory, hypocholesterolemic, immunostimulatory, and antioxidant activities. Further, many gene expression systems such as Escherichia coli and Pichia pastoris have been employed to produce recombinant proteins and peptides. In this chapter, we review the physiological properties of bioactive peptides derived from soybean proteins and discuss the production of soybean peptides by genetic engineering.

\section{The actions and beneficial properties of bioactive peptides from soybean}

Bioactive peptides are usually encrypted in the amino acid sequences of food proteins (Korhonen \& Pihlanto, 2003). Such peptides are inactive within the sequences of precursor proteins, but limited hydrolysis (chemical or fermentation) may unravel the compact protein structures and thereby expose the amino acid residues and patches for inhibiting oxidation. As summarized in Figure 1, soybean-derived bioactive peptides have many beneficial properties, including hypolipidemic and hypocholesterolemic effects, hypotensive effects, improvement in arterial compliance and endothelial function, insulin resistance, and weight loss in obesity (Erdman, 1995; Friedman \& Brandon, 2001; Hermansen et al., 2001; Merritt, 2004; Sirtori et al., 1995).

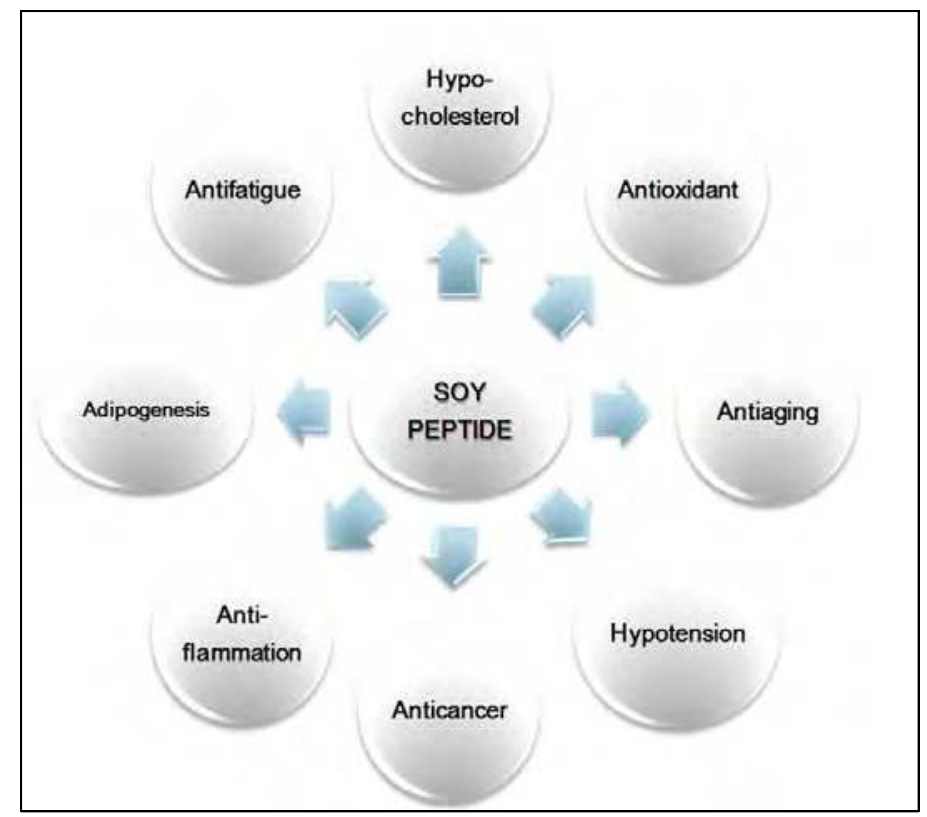

Fig. 1. Beneficial properties of bioactive peptides from soybean. 


\subsection{Hypocholesterolemic activity}

The US Food and Drug Administration has approved health claims concerning the role of soy protein in reducing the risk of coronary heart disease; only people with soy allergy (about $0.5 \%$ of the global population) should avoid eating foods containing soy protein. However, a recent randomized, double-blind, parallel-intervention trial showed no significant effect of soy supplementation ( $30 \mathrm{~g}$ soy protein, $9 \mathrm{~g}$ cotyledon fiber, $100 \mathrm{mg}$ isoflavones) on blood lipid levels compared with a placebo (30 g casein) in hypercholesterolemic subjects after 24 weeks (Hermansen et al., 2005). Therefore, the biological efficacy of a soy protein-rich diet remains controversial. In addition, the final mechanism responsible for plasma cholesterol reduction remains to be elucidated, although nutrigenomic analysis has revealed significant differences in hepatic gene expression concerning lipid and energy metabolism, transcription factor regulation, and antioxidant enzyme production in animals fed soy protein compared with those fed casein (Nagasawa et al., 2002; Takamatsu et al., 2004).

Several studies in cells and validated animal models have suggested that the mechanism of action of soy protein is related to the direct activation of low-density lipoprotein receptors or gene expression in liver cells (Khosla et al., 1989; Lovati et al., 2000; Manzoni et al., 2003), or modulation of both synthesis and catabolism of low-density lipoproteins by specific proportions of dietary amino acids corresponding to soy protein (Lovati et al., 1987; Sirtori et al., 1993; Tovar et al., 2002; Vahouny et al., 1996). Lovati et al. $(1996,2000)$ demonstrated that the smaller major peptide (i.e., 7S globulin) from soy protein, devoid of isoflavone components, inhibits apolipoprotein B secretion and sterol biosynthesis in HepG2 cells. Dietary soy protein hydrolysates not only inhibit the absorption of dietary lipids and increase the absorption of dietary carbohydrates but also augment postprandial energy expenditure, accompanied by a postprandial increase in the oxidation of dietary carbohydrates, in type II diabetic mice (Ishihara et al., 2003).

\subsection{Anti-obesity activity}

Recently, the incidence of obesity has dramatically increased. Obesity is considered a serious problem associated with the development of major human metabolic diseases. This phenomenon occurs as a result of an imbalance between energy intake and energy expenditure that leads to adipocyte accumulation (Aoyama et al., 2000a; Aoyama et al., $2000 \mathrm{~b})$. Therefore, low-energy diets such as a high-protein diet, which helps maintain body protein during restricted energy intake, are used for treating obese patients with diabetes (Hwang et al., 2005).

Obesity is caused by increased adipocyte hyperplasia and hypertrophy as well as fat storage, which induces the transformation of pre-adipocytes into adipocytes (Caro et al., 1989). Nagasawa et al. (2003) reported that soy protein isolates can lower the triglyceride content and fatty acid synthase mRNA level in adipose tissue. Therefore, they suggested that soy protein isolates control the gene expressions in adipose tissue and effectively regulate adipogenesis. Further, the anti-obesity benefits of the black soybean peptide, such as reduction in body weight and adipose tissue weight, have been observed.

Kim et al. (2007) synthesized a tripeptide from soy protein and investigated its activity. In Western blot analysis, the synthetic peptide exhibited a similar inhibitory effect to 5aminoimidazole-4-carboxamide riboside (AICAR), which inhibits the expressions of adipogenic markers and transcription factors for adipogenesis (Haro et al., 1996; Kim et al., 2007). 


\subsection{Anti-inflammatory activity}

Peptide-induced anti-inflammatory activities include modulation of inflammation, binding of toxins, and neutralization of bacteria and fungi. Inflammation associated with skin conditions is often a result of bacterial involvement, partially because of lipopolysaccharide released from the outer membrane of Gram-negative bacteria and lipotechoic acid released from Gram-positive bacteria. Innate-immunity peptides such as defensins and LL-37 are known to bind and neutralize bacterial debris including lipopolysaccharide and lipotechoic acid, resulting in the downregulation of pro-inflammatory cytokines (Mookherjee et al., 2006). Another example is the suppression of propionibacterium acne-stimulated cytokine release by granulysin-derived peptides (McInturff et al., 2005).

Oligopeptide-10 (Granactive Oligopeptide-10; Grant Industries, Elmwood Park, NJ, USA), a synthetic peptide that binds to lipotechoic acid, has been developed for topical anti-acne treatment. It has also shown potential in mitigating symptoms associated with yeast and fungal colonization, such as in dandruff, seborrheic dermatitis, and tinea pedis (Howell, 2007). The combination of oligopeptide-10 with a peptide capable of downregulating cytokine-mediated responses involving interleukin- 6 and interleukin- 8 may have multiple applications, particularly for sensitive skin. Such a product would combine the benefits of binding pro-inflammatory toxins and reducing redness. Recent findings also suggest that a lack of modulation of peptides of the innate system may contribute to various skin conditions (Schauber \& Gallo, 2009). Notably, mounting evidence has shown that overexpression of a pro-inflammatory component of LL-37 is an important contributor to the development of rosacea (Yamasaki et al., 2007).

\subsection{Anticancer activity}

Soy protein may also have anticancer effects. Azuma et al. (2000) and Kanamoto et al. (2001) demonstrated that feeding of an insoluble, high-molecular-weight protein fraction prepared from a proteinase-treated soybean protein isolate suppressed colon and liver tumorigenesis induced by azoxymethane and dietary deoxycholate in experimental animals. Bile acid plays a critical role in liver and colon tumorigenesis. The authors hypothesized that the high-molecular-weight protein fraction exerted these protective effects against colon and liver tumorigenesis by interfering with the enterohepatic circulation of bile acids, thus inhibiting their resorption in the intestine and increasing their fecal excretion. Peptides found in the feces of animals fed with the high-molecular-weight protein fraction were rich in hydrophobic amino acids; therefore, the authors suggested that this protein fraction forms nondissociable complexes with bile acids in the intestine through hydrophobic binding, which are then excreted via feces. High-molecular-weight protein fractions may therefore be used in functional foods to prevent the tumor-promoting activity of bile acids in the liver and colon.

\subsection{Antioxidant activity}

A high level of reactive oxygen species causes DNA, protein, lipid, and carbohydrate damage in the host (Murosaki et al., 2000). Hydrolysates of soy proteins contain antioxidant peptides (Chen et al., 1998). These peptides show high activity against the peroxidation of linoleic acid, paraquat-induced oxidative stress in rats, and scavenging effects on peroxynitrite, active oxygen, and free radical species (Takenaka et al., 2003). They may therefore help prevent some free radical-related diseases. 


\subsection{Hypotensive activity}

The angiotensin-converting enzyme (dipeptidyl carboxypeptidase, EC 3.4.15.1) plays an important role in regulating blood pressure. It increases blood pressure by converting inactive angiotensin I to potent vasoconstrictor angiotensin II and inactivating the vasodilator bradykinin (Yang et al., 1970). Therefore, inhibition of the angiotensinconverting enzyme reduces the activity of angiotensin II and increases the bradykinin level, thus lowering blood pressure.

Soybean is a valuable source of inhibitors of the angiotensin-converting enzyme (Ahn et al., 2000; Shin et al., 2001). Inhibitors of this enzyme are now widely used as antihypertensive agents, causing a fall in blood pressure comparable to that produced by thiazides, and calcium antagonists (Pool et al., 1989). Many peptides isolated by the hydrolysis of food proteins have inhibitory activity against the enzyme and reduce blood pressure after oral administration (Ahn et al., 2000; Je et al., 2004; Yamamoto, 1997). Daily use of food with such peptides may be effective in maintaining blood pressure at the normal level.

\subsection{Anti-fatigue activity}

Exercise-induced fatigue is a listlessness resulting from excessive exertion or "overexercise," leading to diminished bodily and mental functions. It is attributable to the following factors. First, free radicals cause metabolic disturbances; both normal and exhaustive exercises can cause an increase in free radicals in hepatic tissues, resulting in hepatocyte damage (Gul et al., 2006; Voces et al., 1999). Second, exercise causes the production and accumulation of products of metabolism, such as lactic acid. Third, exercise promotes the mobilization and consumption of energy sources such as glycogen (Ikeuchi et al., 2006). In addition, overexercise diminishes the brain's supply of oxygen, which leads to fatigue. Soybean peptides purified by ultrafiltration and gel chromatography have been shown to extend the swimming time of mice, effectively delay increases in their blood lactate level, and enhance the storage of hepatic glycogen.

Soybean peptides are rich in amino acids such as leucine $(23.6 \%)$, valine $(12.22 \%)$, lysine $(10.01 \%)$, isoleucine $(8.8 \%)$, and phenlyalanine $(8.75 \%)$. In addition, soybean peptides contain $4.74 \%$ aspartate and $5.55 \%$ glutamate, which help in performing exercise (Guezennec et al., 1998) and delaying fatigue (Marquezi et al., 2003). A supply of amino acids, especially branched-chain amino acids, can improve exercise ability and markedly retard the catabolism of proteins in muscle during exercise (Blomstrand \& Newsholme, 1992). Bazzarva et al. (1992) indicated that the amount of amino acids, especially alanine, glycine, valine, gamma-aminobutyric acid, isoleucine, threonine, serine, and tyrosine, in the plasma decreases rapidly during endurance testing.

Red mold rice contains alanine, valine, and serine, implying that consumption of this rice can enhance exercise ability via its constituent amino acids. In addition, red mold rice contains gamma-aminobutyric acid and glutamic acid, which have positive effects on the nervous system and could help in executing exercise (Guezennec et al., 1998). Marquezi et al. (2003) indicated that aspartic acid is helpful in oxidative deamination and can lower the blood ammonia concentration, thus delaying fatigue.

\subsection{Anti-aging activity}

Many protein hydrolysates have been used in cosmetic formulations for decades because of their ability to stimulate skin firmness, tone, and elasticity as well as counteract skin aging. Until now, these peptides were poorly studied and their efficacy was poorly demonstrated. 
During aging, the epidermis and dermis become thin; therefore, an efficient anti-aging product should be able to stimulate the metabolism of senescent fibroblasts and keratinocytes in order to increase the quantity of extracellular matrix components such as collagen and glycosaminoglycans. A parallel study performed on an in vitro skin-equivalent model and with human volunteers demonstrated the efficacy of a specific soy biopeptide against aging. This biopeptide induced a significant increase in glycosaminoglycan synthesis both in vitro and in vivo after a one-month treatment. This new cosmetic ingredient was also able to stimulate collagen synthesis in vitro and in vivo (Andre-Frei et al., 1999).

Enzyme-inhibitory peptides directly or indirectly inhibit the activity of enzymes. Protein or peptides naturally extracted from soybean seeds can inhibit the formation of proteinases (Centerchem, Inc., Norwalk, CT, USA). Soy protein is frequently used as an anti-aging, skinmoisturizing, anti-solar, cleansing, and hair-promoting agent. In a randomized, doubleblind, placebo-controlled study (Sudel et al., 2005), soy extract and placebo creams were applied to the volar part of the forearm of 21 healthy women; the papillary index increased to a significantly greater extent with the soy extract cream than with the placebo cream (4.56 vs. 3.76 arbitrary units, $P<0.05)$. Another study with a pseudorandomized design in 10 Caucasian women indicated the superiority of $2 \%$ soy biopeptide emulsion to a placebo in terms of collagen synthesis and stimulation of glycosaminoglycan contents (Andre-Frei et al., 1999).

\section{Bioactive peptides produced by gene expression systems}

In the recent years, various small peptides isolated from proteolytic hydrolysates of food proteins have shown a variety of physiological activities (Fiat et al., 1993), such as modulating the autonomic nerve system, activating the cell immune mechanism, and improving cardiovascular system function. These discoveries are valuable for exploiting functional foods and developing new medicaments.

The expression of heterologous proteins in microorganisms by genetic recombination is still the high point in the development and exploitation of modern biotechnology. An optimal expression system can be selected only if the productivity, bioactivity, purpose, and physicochemical characteristics of the protein of interest are taken into consideration, together with the cost, convenience, and safety of the system itself. E. coli has a typical prokaryotic expression system. Itakura et al. (1977) successfully expressed somatostatin, a mammalian peptide hormone, in E. coli, realizing the in vitro expression of a foreign gene in prokaryotic cells. The cost of the bioactive substance produced in medium was similar to that of the protein extracted from the brains of 500,000 sheep. The event is therefore regarded as a milestone in genetic engineering. To date, reformed $E$. coli has been used extensively as a cellular host for foreign protein expression because of its rapid growth, capacity for continuous fermentation, and relatively low cost. Many commercial expression systems designed for various applications and compatibilities are available. The T7-based pET expression system (Novagen, Merck KGaA, Darmstadt, Germany) is the most commonly used in recombinant protein preparation. In general, three forms of foreign proteins can be expressed in E. coli: fusion proteins, secreted proteins, and inclusion bodies. E. coli cannot perform the post-translational modifications (e.g., $\mathrm{N}$ - and O-linked glycosylation, fatty acid acylation, phosphorylation, and disulfide-bond formation) often required for proper folding of the secondary, tertiary, and quaternary structures as well as for the functional characteristics of the protein of interest. Obviously, these modifications 
can affect the bioactivity, function, structure, solubility, stability, half-life, protease resistance, and compartmentalization of the protein (Jung \& Williams, 1997).

Figure 2 shows strategies to obtain bioactive peptides from soybean. To the best of our knowledge, the use of genetic engineering instead of other synthetic methods to obtain a protein or peptide is both time-saving and cost-effective. We have successfully used a commercial E. coli expression system to express recombinant lunasin (Liu \& Pan, 2010). In the following section, we present a representative method to obtain recombinant lunasin by using an E. coli expression system.

Favorite peptide

Ex: soybean

Purification procedure Strategies for gene cloning and expression

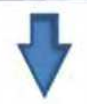

1. Hydrolysate

2. Uitra-filtration

3. Gel filtration chromatography

4. Reverse-phase highperformance liquid chromatography

5. Reverse-phase highperformance liquid chromatography

6. Bioactivity assay and identification

7. Novel peptide discovered
(A)

1. Gene information (NCBI, Pub
Med, or other databases)

2. Design the optimal codon usage and synthesized by overlapping extension polymerase chain reaction (OEPCR)

3. Usually applieded in Prokaryotic gene expression systems
(B)

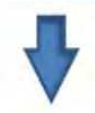

1. mRNA extracted from soybean

2. Reverse transcription (Preparation of cDNA)

3. Usually applied in Prokaryotic and Eukaryotic gene expression systems

Fig. 2. Strategies for the purification and cloning of bioactive peptides from soybean.

\section{Recombinant lunasin}

\subsection{Bioactive lunasin in current research}

Lunasin is a 43-amino acid peptide with nine aspartate residues (D) at the C-terminus, an Arg-Gly-Asp (RGD) cell adhesion motif, and a conserved region of chromatin-binding proteins (Odani et al., 1987a, 1987b). Previous studies showed that lunasin suppresses carcinogenesis triggered by chemical carcinogens and oncogenes both in vitro and in a mouse skin cancer model (Galvez et al., 2001). Hsieh et al. (2010) recently evaluated the anticancer properties of lunasin in breast cancer by using a xenograft mouse model. The US Food and Drug Administration recommends the consumption of $25 \mathrm{~g}$ of soy protein per day to lower cholesterol levels and reduce the risk of heart disease (Xiao, 2008); this supplies approximately $250 \mathrm{mg}$ of lunasin. Whether this dose is sufficient for chemoprevention still needs to be determined. 
In a human feeding trial for detecting the presence of lunasin in plasma after soy protein consumption, lunasin was found in the circulation, a key requirement for its bioactivity in the target organs (Dia et al., 2009). Recently, some studies showed that lunasin can reduce low-density lipoprotein and total cholesterol levels by directly inhibiting gene expression of 3-hydroxy-3-methyl-glutaryl-CoA reductase, which reduces cholesterol biosynthesis, and increasing low-density lipoprotein receptor expression, which enhances clearance of plasma low-density lipoprotein cholesterol (Galvez, 2001). In 2001, Galvez applied the Pichia yeast expression system for large-scale production of lunasin. Besides, lunasin and lunasin-like peptides isolated from defatted soybean flour can inhibit inflammation in lipopolysaccharide-induced RAW 264.7 cells by suppressing the nuclear factor kappa B pathway (de Mejia \& Dia, 2009). In addition, synthetic lunasin has antioxidant properties such as linoleic acid oxidation-inhibitory and 2,2'-azino-bis(3-ethylbenzthiazoline-6sulphonic acid) (ABTS) radical-scavenging activities (Hernández-Ledesma et al., 2009). Recently, lunasin from soybean was found to promote apoptosis of HT-29 colon cells by activating mitochondrial pathways and inducing nuclear clustering (Dia \& de Mejia, 2010).

\subsection{Experimental design involving genetic synthesis}

Figure 3 shows the experimental design for obtaining recombinant lunasin.

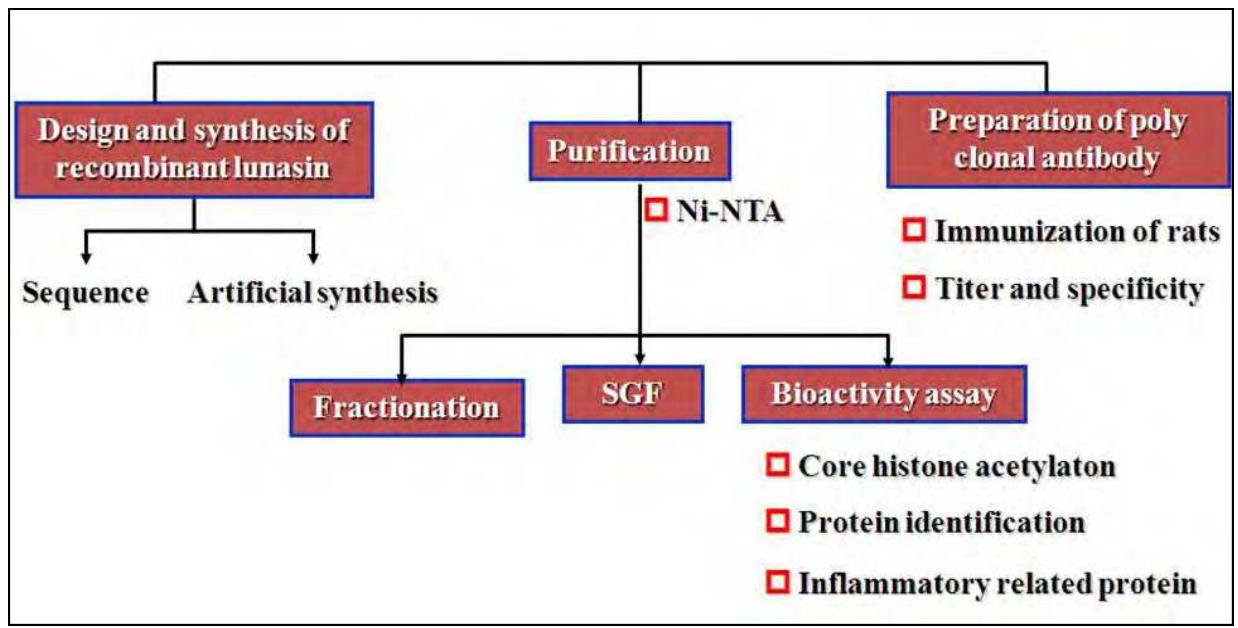

Fig. 3. Flow chart of a method for obtaining recombinant lunasin via E. coli (Liu \& Pan, 2010).

In the experiment, the lunasin sequence from soybean was codon-optimized for high expression in E. coli by changing the original sequence of lunasin (Odani et al., 1987b) to highly frequent codons used in the host. As shown in Figure 4, synthesis of the lunasin gene was achieved by an overlapping extension polymerase chain reaction strategy using four oligonucleotides. 


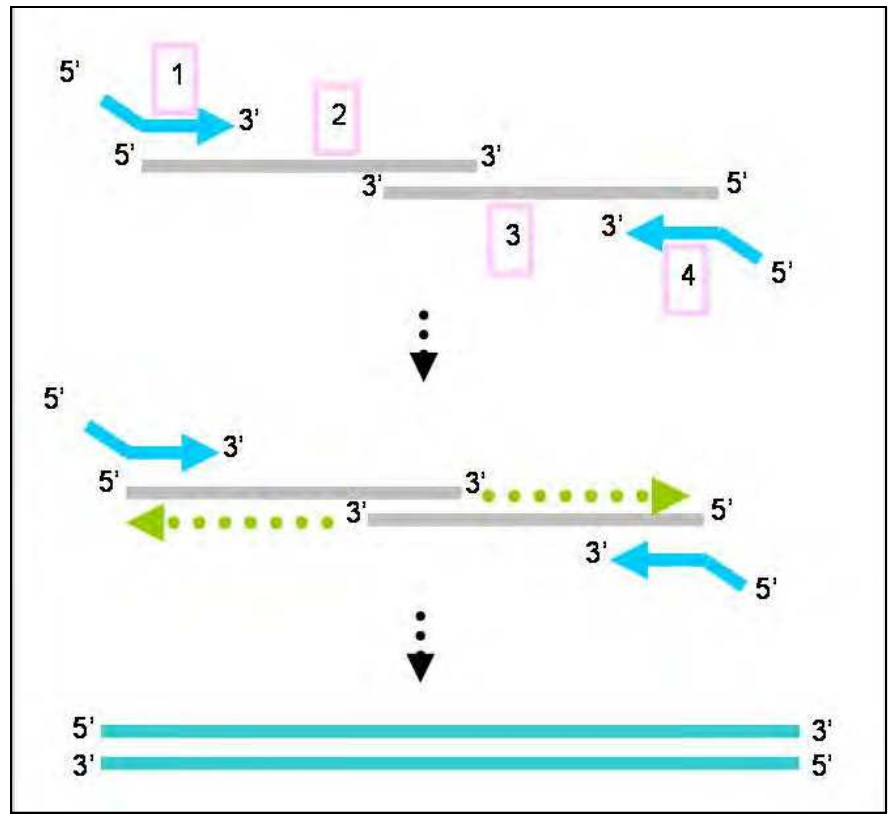

Fig. 4. Schematic of the overlapping extension polymerase chain reaction. Primer 2 and 3 were used as template primers; primer 1 and 4 were used as forward and reverse primers.

\subsection{Purification and production}

Lunasin is a polypeptide derived from the small subunit of soybean cotyledon-specific $2 \mathrm{~S}$ albumin. The current research is based on extraction by plant or chemical synthesis of this polypeptide (Galvez \& de Lumen, 1999). The purification of lunasin from plant sources is tedious. To date, lunasin has been isolated from various plants such as soybean (Odani et al., 1987b), barley (Jeong et al., 2002), herbs (Solanum nigrum L.; Jeong et al., 2007a), wheat (Jeong et al., 2007b), and amaranth (Amaranthus hypochondriacus; Silva-Sanchez et al., 2008). Natural lunasin has been extracted and purified by ion exchange chromatography and immuno-affinity column chromatography. Commercial soy products contain reasonable amounts of lunasin, ranging from $5.48 \mathrm{mg}$ of lunasin per gram of protein (defatted soy flour) to $16.52 \mathrm{mg}$ of lunasin per gram of protein (soy concentrate) (Jeong et al., 2003). The lunasin content of extracts from different varieties of barley ranges from 5.93 to $8.71 \mathrm{mg}$ of lunasin per gram of protein (Jeong et al., 2002) and $36.4 \mathrm{mg}$ of lunasin per gram of protein in Solanum nigrum L extract (Jeong et al., 2007a). Wheat and amaranth extracts have 3.95-17.2 mg lunasin per gram of protein (Jeong et al., 2007b) and $11.1 \mu \mathrm{g}$ lunasin per gram of protein (Silva-Sanchez et al., 2008), respectively.

Some heterologous eukaryotic proteins such as human insulin-like growth factor II, alphainterferon, and interleukin-2 have been expressed in E. coli (Dijkema et al., 1984). In our experiment, recombinant lunasin containing his-tag at the C-terminus was expressed in soluble form, which could be purified by immobilized metal affinity chromatography (Figure 5). After $4 \mathrm{~h}$, the expression level was above $4.73 \mathrm{mg}$ of recombinant his-tagged lunasin per liter of Luria-Bertani broth. This method does not affect the bacterial growth 
and expression levels. Consequently, it is easier to use an E. coli genetic expression system to express a heterologous protein than to extract the protein from plants.

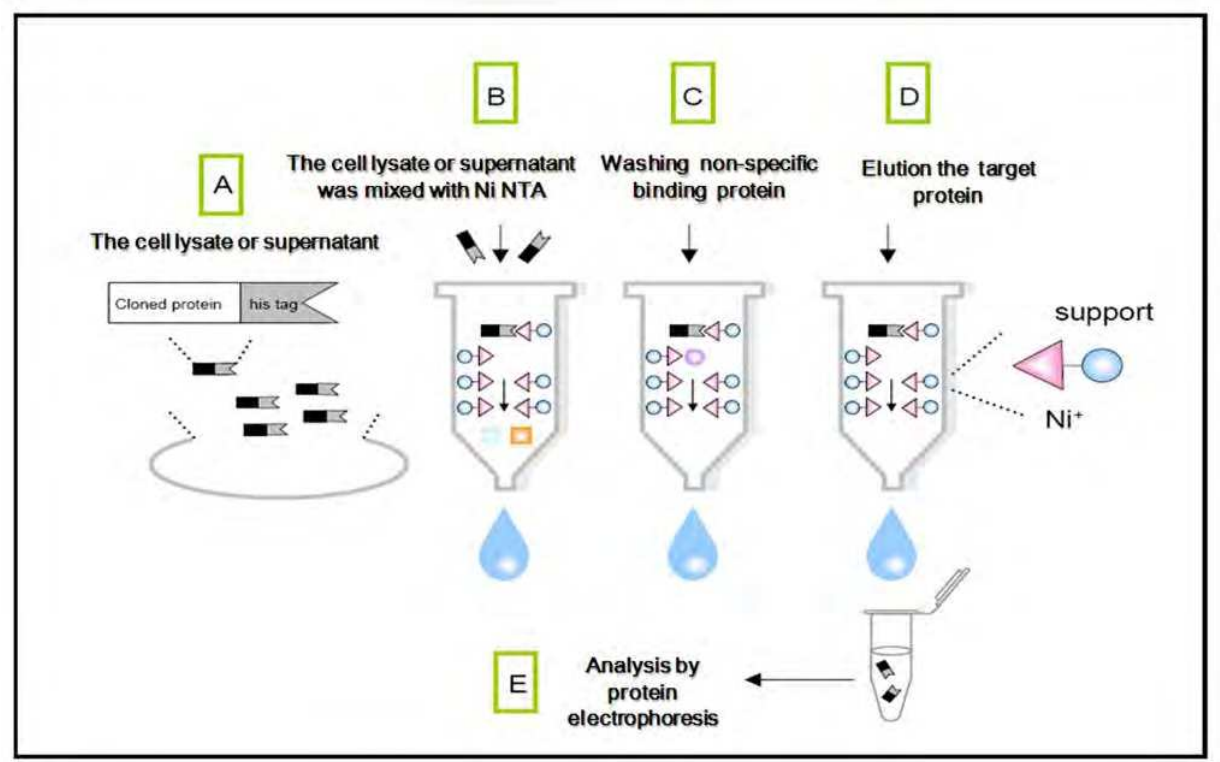

Fig. 5. The flow chart of recombinant lunasin purified by IMAC. (Liu \& Pan, 2010)

\subsection{Bioactivity}

For detecting the bioactivity of the recombinant peptide from E. coli, we used M10 and Raw 264.7 cells to evaluate the levels of histone acetylation and anti-inflammation. We found that recombinant his-tagged lunasin expressed by E. coli decreases acetylation in M10 cells by approximately $26.6 \%$. The results of a histone acetylation assay depend on the cell model and source of lunasin. Galvez et al. (2001) suggested that $2 \mu \mathrm{M}$ of lunasin isolated from soybean can efficiently prevent histone acetylation in $\mathrm{C} 3 \mathrm{H}$ and MCF-7 cells. Jeong et al. (2002) reported that N-butyrate-treated NIH3T3 cells show an approximately 18-fold decrease in $\mathrm{H} 3$ acetylation after treatment with lunasin extract from barley seeds. In MCF7 cells, H3 acetylation can be completely inhibited by lunasin (Jeong et al., 2002). Recombinant his-tagged lunasin is a 92-amino acid peptide, almost double that of native lunasin (43amino acid residues) obtained from plants. The extra amino acid residues at the $\mathrm{N}$ - and Cterminals do not appear to affect the bioactivity of the recombinant protein.

Macrophage activation is associated with a significant proportion of lipopolysaccharideinduced inflammation. During this process, active macrophages produce cytotoxic inflammatory mediators, including reactive oxygen and nitrogen intermediates, hydrolytic enzymes, lipid mediators, and inflammatory cytokines (Laskin \& Pendino, 1995). In lipopolysaccharide-induced macrophages, nitric oxide is mainly produced via inducible nitric oxide synthetase (Knowles \& Moncada, 1994), which is synthesized via the nuclear factor kappa B pathway, similar to tumor necrosis factor-alpha and other pro-inflammatory cytokines such as interleukin-1beta, interleukin-6, and interleukin-12. Dia et al. (2009) were 
the first to indicate that lunasin isolated from defatted soybean flour has some antiinflammatory activity in RAW 264.7 cells; they found lunasin can inhibit the cyclooxygenase 2-prostaglandin E2 and inducible nitric oxide synthetase-nitric oxide pathways. De Mejia and Dia et al (2009) reported that lunasin and lunasin-like peptides purified from defatted soybean flour inhibit inflammation in lipopolysaccharide-induced RAW 264.7 macrophages by suppressing the nuclear factor kappa B pathway. Chemically synthesized lunasin also has some antioxidant and anti-inflammatory properties (Hernández-Ledesma et al., 2009). Recombinant lunasin produced from E. coli can inhibit the release of pro-inflammatory cytokines (tumor necrosis factor-alpha and interleukin-1beta) and nitric oxide production. (Liu \& Pan, 2010)

\section{Conclusion}

We have presented several opportunities for the industrial exploitation of soy-derived bioactive peptides to enhance health and prevent disease. In this chapter, we have introduced the physiological properties of bioactive peptides from soybean and provided an example on the expression of a recombinant peptide by genetic engineering. Choosing the right expression system requires adequate time and makes the difference between success and failure. Once the protein is expressed, a suitable purification scheme can be planned. As shown in Table 1, many bioactive peptides from soybean have been identified and can be applied in genetic expression systems to express important genes.

\begin{tabular}{|l|l|l|}
\hline Biological properties & Peptides & Reference \\
\hline Hypocholesterol peptides & $\begin{array}{l}\text { WGAPSL } \\
\text { Ile-Ala-Glu-Lys } \\
\text { Leu-Pro-Tyr-Pro }\end{array}$ & $\begin{array}{l}\text { Zhong et al., 2007 } \\
\text { Nagaoka et al., 2001 } \\
\text { Kwon et al., 2002 }\end{array}$ \\
\hline Anticancer & $\begin{array}{l}\text { X-Met-Leu-Pro-Ser-Tyr-Ser- } \\
\text { Pro-Tyr }\end{array}$ & Kim et al., 2000 \\
\hline ACE inhibitory peptides & Asp-Leu-Pro & Wu and Ding, 2001 \\
\hline Hypotensive & $\begin{array}{l}\text { Tyr-Val-Val-Phe-Lys } \\
\text { Pro-Asn-Asn-Lys-Pro-Phe- } \\
\text { Gin } \\
\text { Asn-Trp-Gly-Pro-Leu-Val } \\
\text { Ile-Pro-Pro-Gly-Val-Pro-Tyr- } \\
\text { Trp-Thr } \\
\text { Thr-Pro-Arg-Val-Phe } \\
\text { RPLKPW }\end{array}$ & Kodera and Nio, 2002 \\
\hline Antihypertensive & PGTAVFK & Korhonen and Pihlanto, 2003 \\
\hline $\begin{array}{l}\text { Immunostimulating } \\
\text { peptide }\end{array}$ & $\begin{array}{l}\text { MITLAIPVNKPGR } \\
\text { MITLAIPVN } \\
\text { MITL }\end{array}$ & Kitts and Weiler, 2003 \\
\hline Antioxident peptide & LLPHH & Koshikawa et al., 2000 \\
\hline Adipogenesis inhibitor & Ile-Gln-Asn & Kim et al., 2007 \\
\hline
\end{tabular}

Table 1. Some examples of bioactive peptides derived from soybean 


\section{References}

Ahn, S.W.; Kim, K.M.; Yu, K.W.; Noh, D.O. \& Suh, H.J. (2000) Isolation of angiotensin I converting enzyme inhibitory peptide from soybean hydrolysate. Food Science Biotechnology. Vol, 9, No. 3, 378-381. ISSN: 1226-7708.

Andre-Frei, V.; Perrier, E.; Augustin, C.; Damour O.; Bordat, P.; Schumann, K.; Förster, T. \& Waldmann-Laue, M. (1999) A comparison of biological activities of a new soya biopeptide studied in an in vitro skin equivalent model and human volunteers. International Journal of Cosmetic Science. Vol. 21, No. 5, 299-311. ISSN: 0142-5463.

Aoyama, T. Fukui, K.; Nakamori, T.; Hashimoto, Y.; Yamamoto, T.; Takamatsu, K. \& Sugano M. (2000a) Effect of soy and milk whey protein isolates and their hydrolysates on weight reduction in genetically obese mice. Bioscience, Biotechnology, and Biochemistry. Vol. 64, No. 12, 2594-2600. ISSN:0916-8451.

Aoyama, T. Fukui, K.; Takamatsu, K.; Hashimoto, Y. \& Yamamoto, T. (2000b) Soy protein isolate and its hydrolysate reduce body fat of dietary obese rats and genetically obese mice (Yellow KK). Nutrition. Vol. 16, No. 5, 249-254. ISSN: 0899-9007.

Azuma, N.; Machida, K.; Saeki, T.; Kanamoto, R. \& Iwami, K. (2000) Preventive effect of soybean resistant proteins against experimental tumorigenesis in rat colon. Journal of Nutritional Science and Vitaminology. Vol. 46, No. 1, 23-29. ISSN: 0301-4800.

Bazzarva TL, Murdoch DD, Wu SL, Herr DC, Snider IP (1992) Plasma amino acid responses of trained athletes to two successive exhaustion trials with and without interim carbohydrate feeding. Journal of the American College of Nutrition. Vol. 11, No. 5, 501511. ISSN: 0731-5724.

Blomstrand, B. \& Newsholme, E.A. (1992) Effect of branched-chain amino acid supplementation on the exercise-induced change in aromatic amino acid concentration in human muscle. Acta Physiologica Scandinavica. Vol. 146, No. 3, 293298. ISSN: 0001-6772.

Caro, J.F.; Dohm, L.G.; Pories, W.J. \& Sinho, M.K. (1989) Cellular alterations in liver skeletal muscle and adipose tissue responsible for insulin resistance in obesity and type II diabetes. Diabetes Metabolism Reviews. Vol. 5, No. 8, 665-690. ISSN: 0742-4221.

Chen, H.M.; Muramoto, K.; Yamauchi, F.; Fujimoto, K. \& Nokihara, K. (1998) Antioxidative properties of histidine-containing peptides designed from peptide fragments found in the digests of a soybean protein. Journal of Agricultural and Food Chemistry. Vol. 46, No. 1, 49-53. ISSN: 0021-8561.

Cohen, L.A.; Zhao, Z.; Pittman, B.; Scimeca, J.A. (2000) Effect of intact and isoflavonedepleted soy protein on NMU induced rat mammary tumorigenesis. Carcinogenesis, Vol.21, No.5, 929-935. ISSN: 0143-3334.

de Mejia, E.G. \& Dia, V.P. (2009) Lunasin and lunasin-like peptides inhibit inflammation through suppression of NF-kB in the macrophage. Peptides. Vol. 30, No. 12, 23882398. ISSN: 0196-9781.

Dia, V.P.; Wang, W.; Oh, V.L.; de Lumen, B.O. \& de Mejia, E.G. (2009) Isolation, purification and characterisation of lunasin from defatted soybean flour and in vitro evaluation of its anti-inflammatory activity. Food Chemistry Vol. 114, No. 13, 108-115. ISSN: 0308-8146.

Dia, V.P. \& de Mejia, E.G. (2010) Lunasin promotes apoptosis in human colon cancer cells by mitochondrial pathway activation and induction of nuclear clusterin expression. Cancer Letters Vol. 295, No. 1, 44-53. ISSN:. 0304-3835. 
Dijkema, R.; Pouwels, P.; de Reus, A. \& Schellekens, H. (1984) Structure and expression in Escherichia coli of a cloned rat interferonalpha gene. Nucleic Acids Research Vol. 12, No. 2, 1227-1242. ISSN: 03051048.

Erdman, J.J.W. (1995) Control of serum lipids with soy protein. The New England Journal of Medicine, Vol. 333, No. 5, 313-315. ISSN: 0028-4793.

Fiat, A.M.; Migliore-Samour, D.; Jollès, P.; Drouet, L.; Bal dit Sollier, C. \& Caen, J. (1993) Biologically active peptides from milk with emphasis on two examples concerning antithrombotic and immuno-modulating activity. Journal of Dairy Science. Vol. 76, No. 1, 301-310. ISSN: 0022-0302.

Fournier, D.B.; Erdman, J.W. \& Gordon, G.B. (1998) Soy, its components, and cancer prevention: a review of the in vitro, animal, and human data. Cancer Epidemiology, Biomarkers and Prevention, Vol. 7, No. 11, 1055-1065. ISSN: 1055-9965.

Friedman, M. \& Brandon, D.L. (2001) Nutritional and health benefits of soy proteins. Journal of Agricultural and Food Chemistry. Vol. 49, No. 3, 1069-1086. ISSN: 0021-8561.

Fukui, K.; Tachibana, N.; Wanezaki, S.; Tsuzaki, S.; Takamatsu, K.; Yamamoto, T.; Hashimoto, Y. \& Shimoda, T. (2002) Isoflavone free soy protein prepared by column chromatography reduces plasma cholesterol in rats. Journal of Agricultural and Food Chemistry, Vol. 50, No. 20 , 5717-5721. ISSN: 0021-8561.

Galvez, A.F. \& de Lumen, B.O. (1999) A soybean cDNA encoding a chromatin-binding peptide inhibits mitosis of mammalian cells. Nature Biotechnology. Vol. 17, No. 5, 495-500. ISSN: 1087-0156.

Galvez, A.F. (2001) Method of large-scale production and method of testing of the biological activity of a substance from soybean. PCT patent WO 2001/034808

Galvez, A.F.; Chen, N.; Macasieb, J. \& de Lumen, B.O. (2001) Chemopreventive property of a soybean peptide (lunasin) that binds to deacetylated histones and inhibits acetylation. Cancer Research. Vol. 61, No. 20, 7473-7478. ISSN: 0008-5472.

Genovese, M.I. \& Lajolo F.M. (2002) Isoflavones in soy-based foods consumed in Brazil: levels, distribution and estimated intake. Journal of Agricultural and Food Chemistry, Vol. 50, No. 21, 5987-5993. ISSN: 0021-8561.

Gianazza, E.; Eberini, I.; Arnoldi, A.; Wait, R. \& Sirtori C.R. (2003) A proteomic investigation of isolated soy proteins with variable effects in experimental and clinical studies. The Journal of Nutration, Vol. 133, No. 1, 9-14. ISSN: 0022-3166.

Guezennec, C.Y.; Abdelmalki, A. \& Serrurier, B. (1998) Effect of prolonged exercise on brain ammonia and amino acids. International Journal of Sports Medicine. Vol. 19, No. 5, 323-327. ISSN: 0172-4622.

Gul, M.; Demircan, B.; Taysi, S.; Oztasan, N.; Gumustekin, K.; Siktar, E.; Polat, M.F.; Akar, S.; Akcay, F. \& Dane, S. (2006) Effects of endurance training and acute exhaustive exercise on antioxidant defense mechanism in rat heart. Comparative Biochemistry and Physiology. Part A, Molecular \& Integrative Physiology Vol. 143, No. 2, 239-245. ISSN: 1095-6433.

Haro, C.D.; Mendez, R. \& Santoyo, J. (1996) The eIF-2a kinases and the control of protein synthesis. Federation of American Societies for Experimental Biology. Vol. 10, No. 12, 1378-1387. ISSN: 0892-6638.

Hermansen, K.; Hansen, B.; Jacobsen, R.; Clausen, P.; Dalgaard, M. Dinesen, B.; Holst, J.J.; Pedersen, E. \& Astrup, A. (2005) Effects of soy supplementation on blood lipids and arterial function in hypercholesterolaemic subjects. European Journal of Clinical Nutrition. Vol. 59, No. 7, 843-850. ISSN: 0954-3007. 
Hermansen, K.; Sondergaard, M.; Hoie, L.; Carstensen, M. \& Brock, B. (2001) Beneficial effects of a soy-based dietary supplement on lipid levels and cardiovascular risk markers in type 2 diabetic subjects. Diabetes Care. Vol. 24, No. 2, 228-233. ISSN: 0149-5992.

Hernández-Ledesma, B.; Hsieh, C.C. \& Lumen, B.O. (2009) Antioxidant and antiinflammatory properties of cancer preventive peptide lunasin in RAW 264.7 macrophages. Biochemical and Biophysical Research Communications. Vol. 390, No. 3, 803-808. ISSN: 0006-291X.

Howell, M.D. (2007) The role of human beta defensins and cathelicidins in atopic dermatitis. Current Opinion in Allergy and Clinical Immunology. Vol. 7, No. 5, 413-417. ISSN: 7528-4050.

Hsieh, C.C.; Henandez-Ledesma, B.; Jeong, H.J.; Park, J.H. \& de Lumen, B.O. (2010) Complementary roles in cancer prevention: protease inhibitor makes the cancer preventive peptide lunasin bioavailable. Public Library of Science One. Vol. 5, No. 1, e8890. ISSN: 1932-6203.

Hwang, J.T.; Park, I.J.; Shin, J.I.; Lee, Y.K.; Lee, S.K.; Baik, H.W.; Ha, J. \& Park, O.J. (2005) Genistein, EGCG, and capsaicin inhibit adipocyte differentiation process via activating AMP-activated protein kinase. Biochemical and Biophysical Research Communications. Vol. 338, No. 2, 694-699. ISSN: 0006-291x.

Ikeuchi, M.; Koyama, T.; Takahashi, J. \& Yazawa. K. (2006) Effects of astaxanthin supplymentation on exercise-induced fatigue in mice. Biological $\mathcal{E}$ Pharmaceutical Bulletin. Vol, 29, No. 10, 2106-2110. ISSN: 0918-6158.

Ishihara, K.;, Oyaizu, S.; Fukuchi, Y.; Mizunoya, W.; Segawa, K.; Takahashi, M.; Mita, Y.; Fukuya, Y.; Fushiki, T. \& Yasumoto, K. (2003) A soybean peptide isolate diet promotes postprandial carbohydrate oxidation and energy expenditure in type II diabetic mice. The Journal of Nutrition. Vol. 133, No. 3, 752-757. ISSN: 0022-3166.

Itakura, K.; Hirose, T.; Crea, R.; Riggs, A.D.; Heyneker, H.L.; Bolivar, F. \& Boyer, H.W. (1977) Expression in Escherichia coli of a chemically synthesized gene for the hormone somatostatin. Science Vol. 198, No. 4321, 1056-1063. ISSN: 0193-4911.

Je, J.Y.; Park, P.J.; Kwon, J.Y. \& Kim, S.K. (2004) A novel angiotensin I converting enzyme inhibitory peptide from Alaska pollock (Theragra chalcogramma) frame protein hydrolysate. Journal of Agricultural and Food Chemistry. Vol. 52, No. 26, 7842-7845. ISSN: 0021-8561.

Jeong, H.J.; Jeong, J.B.; Kim, D.S.; Park, J.H.; Lee, J.B.; Kweon, D.H.; Chung, G.Y.; Seo, E.W. \& de Lumen, B.O. (2007b) The cancer preventive peptide lunasin from wheat inhibits core histone acetylation. Cancer Letters. Vol. 255, No. 1, 42-48. ISSN: 03043835 .

Jeong, H.J.; Lam, Y.. \& de Lumen, B.O. (2002) Barley lunasin suppresses ras-induced colony formation and inhibits core histone acetylation in mammalian cells. Journal of Agricultural and Food Chemistry. Vol. 50, No. 21, 5903-5908. ISSN: 0021-8561.

Jeong, H.J.; Park, J.H.; Lam, Y. \& de Lumen, B.O. (2003) Characterization of lunasin isolated from soybean. Journal of Agricultural and Food Chemistry. Vol. 51, No. 27, 7901-7906. ISSN: 0021-8561.

Jeong, J.B.; Jeong, H.J.; Park, J.H.; Lee, S.H.; Lee, J.R.; Lee, H.K.; Chung, G.Y.; Choi, J.D. \& de Lumen, B.O. (2007a) Cancer-preventive peptide lunasin from Solanum nigrum L. inhibits acetylation of core histones $\mathrm{H3}$ and $\mathrm{H} 4$ and phosphorylation of 
retinoblastoma protein $(\mathrm{Rb})$. Journal of Agricultural and Food Chemistry. Vol . 55, No. 26, 10707-10713. ISSN: 0021-8561.

Jung, E. \& Williams, K.L. (1997) The production of recombinant glycoproteins with special reference to simple eukaryotes including Dictyostelium discoideum. Biotechnology and Applied Biochemistry. Vol. 25, No. 1, 3-8. ISSN: 0885-4513.

Kanamoto, R.; Azuma, N.; Miyamoto, T.; Saeki, T.; Tsuchihashi, Y. \& Iwami, K. (2001) Soybean resistant proteins interrupt an enterohepatic circulation of bile acids and suppress liver tumorigenesis induced by azoxymethane and dietary deoxycholate in rats. Bioscience, Biotechnology, and Biochemistry. Vol. 65, No. 4, 999-1002. ISSN: 0916-8451.

Khosla, P.; Samman, S.; Carroll, K.K. \& Huff, M.W. (1989) Turnover of 125I-VLDL and 131ILDL apolipoprotein B in rabbits fed diets containing casein or soy protein. Biochimica et Biophysica Acta. Vol. 1002, No. 2, 157-163. ISSN: 0006-3002.

Kim, H.J.; Bae, I.Y.; Ahn, C.W.; Lee, S. \& Lee, H.G. (2007) Purification and identification of adipogenesis inhibitory peptide from black soybean protein hydrolysate. Peptides. Vol. 28, No. 11, 2098-2103. ISSN: 0196-9781.

Kim, S.E.; Kim, H.H.; Kim, J.Y.; Kang, Y.I.; Woo, H.J. \& Lee, H.J. (2000) Anticancer activity of hydrophobic peptides from soy proteins. Biofactors. Vol. 12, No. 1-4, 151-155. ISSN: 0951-6433.

Kitts, D.D. \& Weiler, K. (2003) Bioactive proteins and peptides from food sources. Applications of bioprocesses used in isolation and recovery. Current Pharmaceutical Design. Vol. 9, No. 16, 1309-1323. ISSN: 1381-6128.

Knowles R.G. \& Moncada S. (1994) Nitric oxide synthases in mammals. The Biochemical Journal Vol. 298, No. 2, 249-258. ISSN: 0264-6021.

Kodera, T, Nio, N. (2002) Aggiotensin converting enzyme inhibitors. PCT Internation Applied WO 2002055546 A1 1843 p. kokai Tokkyo Koho.

Korhonen, H. \& Pihlanto, A. (2003) Food-derived bioactive peptides-opportunities for designing future foods. Current Pharmaceutical Design, Vol. 9, No. 16, 1297-1308. ISSN: 1381-6128.

Kulling, S.E. ; Honig, D.M. \& Metzler, M. (2001) Oxidative metabolism of the soy isoflavones daidzein and genistein in humans in vitro and in vivo. Journal of Agricultural and Food Chemistry, Vol. 49, No. 6 , 3024-3033. ISSN: 0021-8561.

Kwon, D.Y.; Oh, S.W.; Lee, J.S.; Yang, H.J.; Lee, S.H.\& Lee, J.H. (2002) Amino acid substitution of hypocholesterolemic peptide originated from glycinin hydrolyzate. Food Science Biotechnology, Vol. 11, No. 3, 55-61. ISSN: 1226-7708.

Laskin, D.L. \& Pendino, K.J. (1995) Macrophages and inflammatory mediators in tissue injury. Annual Review of Pharmacology and Toxicology. Vol. 35, 655-677. ISSN: 03621642.

Liu, C.F. \& Pan, T.M. (2010) Recombinant expression of bioactive peptide lunasin in Escherichia coli. Applied Microbiology and Biotechnology. Vol. 88, No. 1, 177-186. ISSN: 0175-1598.

Lovati, M.R.; Manzoni, C.; Canavesi, A.; Sirtori, M.; Vaccarino, V.; Marchi, M.; Gaddi, G. \& Sirtori, C.R. (1987) Soybean protein diet increases low density lipoprotein receptor activity in mononuclear cells from hypercholesterolemic patients. The Journal of Clinical Investigation. Vol. 80, No. 5, 1498-1502. ISSN: 0021-9738.

Lovati, M.R.; Manzoni, C.; Corsini, A.; Granata, A.; Fumagalli, R. \& Sirtori, C.R. (1996) $7 S$ globulin from soybean is metabolized in human cell cultures by a specific uptake 
and degradation system. The Journal of Nutrition. Vol. 126, No. 11, 2831-2842. ISSN: 0022-3166.

Lovati, M.R.; Manzoni, C.; Gianazza, E.; Arnoldi, A.; Kurowska, E.; Carroll, K.K. \& Sirtori, C.R. (2000) Soy protein peptides regulate cholesterol homeostasis in Hep G2 cells. The Journal of Nutrition. Vol. 130, No. 10, 2543-2549. ISSN: 0022-3166.

Manzoni, C.; Duranti, M.; Eberini, I.; Scharnag, H.; Marz, W.; Castiglioni, S. \& Lovati, M.R. (2003) Subcellular localization of soybean 7S globulin in HepG2 cells and LDL receptor up-regulation by its alpha constituent subunit. The Journal of Nutrition. Vol. 133, No. 7, 2149-2155. ISSN: 0022-3166.

Marquezi, M.L.; Roschel, H.A.; Costa, A.D.S.; Sawada, L.A. \& Lancha, A.H. (2003) Effect of aspartate and asparagine supplementation on fatigue determinants in intense exercise. International Journal of Sport Nutrition and Exercise Metabolism. Vol, 13, No. 1, 65-67. ISSN: 1526-484X.

McInturff, J.E.; Wang, S.J.; Machleidt, T.; Lin, T.R.; Oren, A.; Hertz, C.J.; Krutzik, S.R.; Hart, S.; Zeh, K.; Anderson, D.H.; Gallo, R.L.; Modlin, R.L. \& Kim, J. (2005) Granulysinderived peptides demonstrate antimicrobial and anti-inflammatory effects against Propionibacterium acnes. The Journal of Investigative Dermatology. Vol. 125, No. 2, 256263. ISSN: 0022-202x.

Merritt, J.C. (2004) Metabolic syndrome: soybean foods and serum lipids. Journal of the National Medical Association. Vol. 96, No. 8, 1032-1041. ISSN: 0027-9684.

Messina, M. \& Flickinger, B. (2002). Hypothesized anticancer effects of soy: evidence points to isoflavones as the primary anticarcinogens. Pharmaceutical Biology, Vol. 4, 6-23. ISSN: 1388-0209.

Messina, M. (2000) Soyfoods and soybean phyto-oestrogens (isoflavones) as possible alternatives to hormone replacement therapy (HRT). European Journal of Cancer, Vol. 36, No. 4, 71-72. ISSN: 0959-8049.

Messina, M.J. \& Loprinzi, C.L. (2001) Soy for breast cancer survivors: a critical review of the literature. The Journal of Nutrition, Vol. 131, No. 11, 3095-3108. ISSN: 0022-3166.

Mookherjee, N.; Brown, K.L.; Bowdish, D.M.; Doria, S.; Falsafi, R.; Hokamp, K.; Roche, F.M.; $\mathrm{Mu}$, R.; Doho, G.H.; Pistolic, J.; Powers, J.P.; Bryan, J.; Brinkman, F.S. \& Hancock, R.E. (2006) Modulation of the TLR-mediated inflammatory response by the endogenous human host defense peptide LL-37. Journal of Immunology. Vol. 176, No. 4, 2455-2464. ISSN: 0022-1767.

Murosaki, S.; Muroyama, K.; Yamamoto, Y. \& Yoshikai, Y. (2000) Antitumor effect of heatkilled Lactobacillus plantarum L-137 through restoration of impaired interleukin-12 production in tumor-bearing mice. Cancer Immunology, Immunotherapy. Vol. 49, No. 3, 157-164. ISSN: 0340-7004.

Nagaoka, S.; Futamura, Y.; Miwa, K.; Awano, T.; Yamauchi, K.; Kanamaru, Y.; Tadashi, K. \& Kuwata, T. (2001) Identification of novel hypocholesterol peptides derived from bovine milk beta-lactoglobulin. Biochemistry Biophysics Research Communication. Vol. 28, No. 1, 11-17. ISSN: 0006-291X.

Nagasawa, A.; Fukui, K.; Funahashi, T.; Maeda, N.; Shimomura, I.; Kihara, S.; Waki, M. Takamatsu, K. \& Matsuzawa, Y. (2002) Effects of soy protein diet on the expression of adipose genes and plasma adiponectin. Hormone and Metabolic Research. Vol. 34, No. 11-12, 635-639. ISSN: 0170-5903.

Nagasawa, A.; Fukui, K.; Kojima, M.; Kishida, K.; Maeda, N.; Nagaretani, H.; Hibuse, T.; Nishizawa, H.; Kihara, S. \& Waki, M. Takamatsu K, Funahashi T, Matsuzawa Y. 
(2003) Divergent effects of soy protein diet on the expression of adipocytokines. Biochemical and Biophysical Research Communications. Vol. 311, No. 4, 909-914. ISSN: 0006-291x

Odani, S.; Koide, T. \& Ono, T. (1987a) Amino acid sequence of a soybean (Glycine max) seed polypeptide having a poly (L-aspartic acid) structure. The Journal of Biological Chemistry. Vol. 262, No. 22, 10502-10505. ISSN: 0021-9258.

Odani, S.; Koide, T.; Ono, T.; Seto, Y. \& Tanaka, T. (1987b) Soybean hydrophobic protein. Isolation, partial characterization and the complete primary structure. European Journal of Biochemistry. Vol. 162, No. 3, 485-491. ISSN: 0014-2956.

Persky, V.W. ; Turyk, M.E.; Wang, L.; Freels, S.; Chatterton, R.J.; Barnes, S.; Erdman J.J.; Sepkovic, D.W.; Bradlow, H.L. \& Potter, S. (2002) Effect of soy protein on endogenous hormones in postmenopausal women. American Society for Clinical Nutrition, Vol. 75, No. 1, 145-153. ISSN: 0002-9165.

Pool, J.L.; Smith, S.G.; Nelson, E.B.; Taylor, A.A. \& Gomez, H.J. (1989) Angiotensinconverting enzyme inhibitors compared with thiazide diuretics or beta-blockers as monotherapy for treatment of mild essential hypertension. Current Opinion Cardiology. Vol. 4, 11-15. ISSN: 0268-4705.

Schauber, J. \& Gallo, R.L. (2009) Antimicrobial peptides and the skin immune defense system. The Journal of Allergy and Clinical Immunology. Vol. 124, No. 3, 13-18. ISSN: 0091-6749.

Setchell, K.D.R. (1998) Phytoestrogens: the biochemistry, physiology, and implications for human health of soy isoflavones. American Society for Clinical Nutrition, Vol. 68 No. 6, 1333-1346. ISSN: 0002-9165.

Shin, Z.I.; Yu, R.; Park, S.A.; Chung, D.K.; Ahn, C.W. \& Nam, H.S. (2001) An angiotensin I converting enzyme inhibitory peptide derived from Korean soybean paste, exerts anti-hypertensive activity in vivo. Journal of Agricultural and Food Chemistry. Vol. 49, No. 6, 3004-3009. ISSN: 0021-8561.

Silva-Sanchez, C..; de la Rosa, A.P.; Leon-Galvan, M.F.; de Lumen, B.O.; de Leon-Rodriguez, A. \& de Mejia, E.G. (2008) Bioactive peptides in Amaranth (Amaranthus hypochondriacus) seed. Journal of Agricultural and Food Chemistry. Vol . 56, No. 4, 1233-124. ISSN: 0021-8561.

Sirtori, C.R.; Even, R. \& Lovati, M.R. (1993) Soybean protein diet and plasma cholesterol: from therapy to molecular mechanisms. Annals of the New York Academy of Sciences. Vol. 676, 188-201. ISSN: 0077-8923.

Sirtori, C.R.; Lovati, M.R.;, Manzoni, C.; Monetti, M. Pazzucconi, F. \& Gatti, E. (1995) Soy and cholesterol reduction: clinical experience. The Journal of Nutrition. Vol. 125, No. 3, 598-605. ISSN: 0022-3166.

Sudel, K.M.; Venzke, K.; Mielke, H.; Breitenbach, U.; Mundt, C.; Jaspers, S.; Koop, U.; Sauermann, K.; Knussman-Hartig, E.; Moll, I.; Gercken, G.; Young, A.R.; Stäb, F.; Wenck, H. \& Gallinat, S. (2005) Novel aspects of intrinsic and extrinsic aging of human skin: beneficial effects of soy extract. Photochemistry and Photobiology. Vol. 81, No. 3, 581-587. ISSN: 0031-8655.

Takamatsu, K.; Tachibana, N.; Matsumoto, I. \& Abe, K. (2004) Soy protein functionality and nutrigenomic analysis. Biofactors. Vol. 21, No. 1-4, 49-53. ISSN: 09516433.

Takenaka, A.; Annaka, H.; Kimura, Y.; Aoki, H. \& Igarashi, K. (2003) Reduction of paraquatinduced oxidative stress in rats by dietary soy peptide. Bioscience, Biotechnology, and Biochemistry. Vol, 67. No. 2, 278-283. ISSN: 0916-8451. 
Tikkanen, M.J. \& Adlercreutz, H. (2000) Dietary soy-derived isoflavone phytoestrogens. Could they have a role in coronary heart disease prevention? Biochemical Pharmacology, Vol. 60, No. 1, 1-5. ISSN : 0006-2952.

Tovar, A.R.; Murguia, F.; Cruz, C.; Hernandez-Pando, R.; Aguilar-Salinas, C.A.; PedrazaChaverri, J.; Correa-Rotter, R. \& Torres, N.A. (2002) Soy protein diet alters hepatic lipid metabolism gene expression and reduces serum lipids and renal fibrogenic cytokines in rats with chronic nephrotic syndrome. The Journal of Nutrition. Vol. 132, No. 9, 2562-2569. ISSN: 0022-3166.

Tsai, P. \& Huang, P. (1999) Effects of isoflavones containing soy protein isolate compared with fish protein on serum lipids and susceptibility of low density lipoprotein and liver lipids to in vitro oxidation in hamsters. The Journal of Nutritional Biochemistry, Vol. 10, No. 11, 631-637. ISSN: 0955-2863.

Vahouny, G.V.; Adamson, I.; Chalcarz, W.; Satchithanandam, S.; Muesing, R.; Klurfeld, D.M.; Tepper, S.A.; Sanghvi, A. \& Kritchevsky, D. (1996) Effects of casein and soy protein on hepatic and serum lipids and lipoprotein lipid distributions in the rat. Atherosclerosis Vol. 56, No. 2, 127-137. ISSN: 0021-9150.

Voces, J.; Alvarez, AI.; Vila, L.; Ferrando, A.; Cabral de Oliveira, C. \& Prieto, J.G. (1999) Effects of administration of the standardized Panax ginseng extract G115 on heptic antioxidant function after exhaustive exercise. Comparative Biochemistry and Physiology. Part C, Pharmacology, Toxicology \& Endocrinology,Vol. 123, No. 2, 175-184. ISSN: 1367-8280.

Wu, J. \& Ding, X. (2001) Hypotensive and physiological effect of angiotensin converting enzyme inhibitory peptides derived from soy protein on spontaneously hypertensive rats. Journal of Agricultural and Food Chemistry, Vol. 49, No. 1, 501-506. ISSN: 0021-8561.

Xiao, C.W. (2008) Health effects of soy protein and isoflavones in humans. The Journal of Nutrition. Vol. 138, No. 6, 1244S-1249S. ISSN: 0022-3166.

Yamamoto, N. (1997) Antihypertensive peptides derived from food proteins. Biopolymers Vol. 43, No. 2, 129-134. ISSN: 0006-3525.

Yamasaki, K.; Di Nardo, A.; Bardan, A.; Murakami, M.; Ohtake, T.; Coda, A.; Dorschner, R.A.; Bonnart, C.; Descargues, P.; Hovnanian, A.; Morhenn, V.B. \& Gallo, R.L. (2007) Increased serine protease activity and cathelicidin promotes skin inflammation in rosacea. Nature Medicine. Vol. 13, No. 8, 975-980. ISSN: 1078-8956.

Yang, H.Y.T.; Erdos, E.G. and Levin, Y. (1970) A dipeptidyl carboxypeptidase that converts angiotensin I and inactivates bradykinin. Biochimica et Biophysica Acta. Vol. 214, No. 2, 374-376. ISSN: 0006-3002.

Yoshikawa, M.; Fujita, H.; Matoba, N.; Takenaka, Y.; Yamamoto, T.; Yamauchi, R.; Tsuruki, H. \& Takahata, K. (2000) Bioactive peptides derived from food proteins preventing lifestyle-related diseases. Biofactors. Vol. 12, No. 1-4, 143-146. ISSN: 0951-6433.

Zhong, F.; Zhang, X.; Ma, J. \& Shoemaker, C.F. (2007) Fractionation and identification of a novel hypocholesterolemic peptide derived from soy protein alcalase hydrolysates. Food Research International. Vol. 40, No. 1, 759-762. ISSN: 0963-9969. 


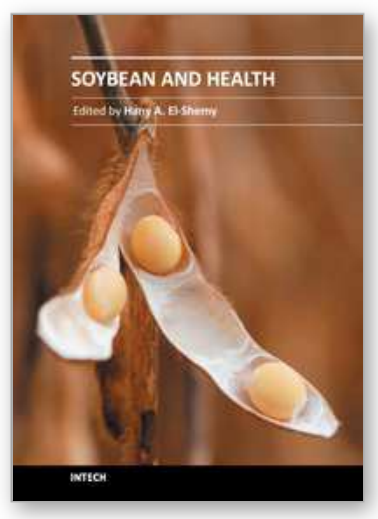

\author{
Soybean and Health \\ Edited by Prof. Hany El-Shemy
}

ISBN 978-953-307-535-8

Hard cover, 502 pages

Publisher InTech

Published online 12, September, 2011

Published in print edition September, 2011

Worldwide, soybean seed proteins represent a major source of amino acids for human and animal nutrition. Soybean seeds are an important and economical source of protein in the diet of many developed and developing countries. Soy is a complete protein, and soy-foods are rich in vitamins and minerals. Soybean protein provides all the essential amino acids in the amounts needed for human health. Recent research suggests that soy may also lower risk of prostate, colon and breast cancers as well as osteoporosis and other bone health problems, and alleviate hot flashes associated with menopause. This volume is expected to be useful for student, researchers and public who are interested in soybean.

\title{
How to reference
}

In order to correctly reference this scholarly work, feel free to copy and paste the following:

Chin Feng Liu and Tzu Ming Pan (2011). Beneficial Effects of Bioactive Peptides Derived from Soybean on Human Health and Their Production by Genetic Engineering, Soybean and Health, Prof. Hany El-Shemy (Ed.), ISBN: 978-953-307-535-8, InTech, Available from: http://www.intechopen.com/books/soybean-and-

health/beneficial-effects-of-bioactive-peptides-derived-from-soybean-on-human-health-and-their-production-b

\section{INTECH}

open science | open minds

\section{InTech Europe}

University Campus STeP Ri

Slavka Krautzeka 83/A

51000 Rijeka, Croatia

Phone: +385 (51) 770447

Fax: +385 (51) 686166

www.intechopen.com

\section{InTech China}

Unit 405, Office Block, Hotel Equatorial Shanghai

No.65, Yan An Road (West), Shanghai, 200040, China

中国上海市延安西路65号上海国际贵都大饭店办公楼405单元

Phone: +86-21-62489820

Fax: +86-21-62489821 
(C) 2011 The Author(s). Licensee IntechOpen. This chapter is distributed under the terms of the Creative Commons Attribution-NonCommercialShareAlike-3.0 License, which permits use, distribution and reproduction for non-commercial purposes, provided the original is properly cited and derivative works building on this content are distributed under the same license. 